\title{
Reflections of a Computer Poet on American Social Dynamics (Or How This Makes Sense)
}

\author{
Sergei Manzhos \\ Department of Mechanical Engineering, National University of Singapore, Singapore, Singapore \\ Email: mpemanzh@nus.edu.sg
}

Received 2 February 2014; revised 5 March 2014; accepted 1 April 2014

Copyright (C) 2014 by author and Scientific Research Publishing Inc.

This work is licensed under the Creative Commons Attribution International License (CC BY). http://creativecommons.org/licenses/by/4.0/

(c) (i) Open Access

\begin{abstract}
We analyze computer-generated poems written with a mesostomatic algorithm. We show that computer-generated poetry is meaningful in the same way as human-generated poetry and that this poetic meaning must renounce one-to-one correspondence to reality, objective or subjective. We further show that the ability of a computer poet to produce meaning is stable with respect to a change in language. On this basis, the computer poet's reflections on some events in modern American history are analyzed by close reading.
\end{abstract}

\section{Keywords}

\section{Computer-Generated Poetry, Modernism, Mesostomatic, Meaning}

\section{Introduction}

Are computer-generated poems meaningful or do they simply provide material from which people can produce meaningful objects, performing a similar role to that that bird songs and marching bands played for Messiaen and Ives? (Watkins, 1995; Struble, 1995). On the answer to this question also depends if poetry can maintain its status as an art form. The answer depends on what kind of meaning can be expected from poetry as art and on what we define as meaning. Understanding such meaning also obviously defines what can be called a creative work if we assume that art needs to be meaningful. A negative answer at any point in time does not preclude the potential of computers to be creative in the future. However, showing that at least some works of computer poets are meaningful in the same sense as works of human poets which are considered "art" would prove a larger statement of computer creativity or, inversely, of a material origin of creativity. "Summer light bears a likeness to justice" sounds poetic and moving even though it is written by a computer code (Mac Low, 1999). Is this a happy coincidence? A subset of works which are found pleasurable or interesting or moving and meaningful can be arbitrarily small; they still may not be written off as a coincidence depending on what kind of meaning they 
possess.

Here, we will analyze two mesostic (Pritchett, 1996) poems generated by an algorithm and attempt to determine if they are meaningful and in what way. To this end, we will give the poems titles evocative- but only indirectly — of a subject, in this case modern American sociopolitics, and perform a close reading of the poems based on that subject and disregarding their computer origin. The poems are written in two languages, English and German, and in this way, we will also study (and confirm) the extra-lingual meaningfulness of poems written by one and the same algorithm. This will lead us to argue that computer-generated poems are meaningful in the same way as human-generated poems. We will discuss what this means for the critical work and how this is reconciled with the possibility of commoditization offered by computerization and other aspects of it usually associated with destruction of artistic value.

\section{Methods}

Mesostic poems were generated with the code Mesostomatic provided by the University of Pennsylvania (McCabe), referred to below as "the poet". A mesostic poem is made by aligning a piece of text called "spine" vertically, i.e. one letter per line, and then generating each line of the poem (in our case consisting of a single word) so that it contains that letter but only one instance of it. The words used to generate the poem are selected from the so-called "oracle" text by reading through it sequentially.

Two case-study poems were generated which take the spine and the oracle texts from different types of sources, including a computer-generated oracle in Poem 1. The spine and the oracle of Poem 1 are in English and do not explicitly refer to events from modern and contemporary American history, while those of Poem 2 are in German and do so. We stress that these poems were not cherry-picked to facilitate interpretation and close reading, but the possibility to make meaningful close readings was confirmed for other source texts as well. Details are as follows:

Poem 1

The spine

The spine is "A number of shorts left him covered with warts", which is a line taken from a poem in Thomas Pynchon's "Gravity's rainbow" (Pynchon, 2000):

There was a young man named McGuire,

Who was fond of the pitch amplifier.

But a number of shorts

Left him covered with warts,

And set half the bedroom on fire

The oracle

The oracle was generated by an algorithm by Scott Pakin (Pakin, 2012). It is:

It seems that before I launch into this letter, I should tell you that the experts agree with me that Penn's up to its neck in criminal activity. I begin with critical semantic clarifications. First, Penn's niddering sound bites often resemble an inverted fairy tale in that the triumph of innocence comes at the start and the ugly sisters of interdenominationalism and lexiphanicism enter on stage in triumph for the final curtain. Penn's list of sins is long and each one deserves more space than I have here. Therefore, rather than describe each one individually, I'll summarize by stating that it acts as if it were King of the World. This hauteur is astonishing, staggering, and mind-boggling.

Although it requires risk, commitment, and follow-through to challenge Penn's claims of exceptionalism, it's easy enough to hate Penn any day of the week on general principles. But now I'll tell you about some very specific things that Penn is up to, things that ought to make a real Penn-hater out of you. First off, by indiscriminately assigning value to practically everything, it has made "experience" all-important. Penn's experiences, however, are detached from any consideration of what is good or true, which means that they will almost certainly break us up into a set of quarreling, wrangling, squabbling factions sometime soon. Before you declare me poxy, let me assert that there is more at play here than Penn's purely political game of goading judgmental, imprudent barmpots into hurling epithets at its adversaries. There are ideologies at work, hidden agendas to insist that our society be infested with plagiarism, nosism, recidivism, and an impressive swarm of other "isms". 
Every time Penn tells its flacks that we ought to worship pestilential whiners as folk heroes, their eyes roll into the backs of their heads as they become mindless receptacles of unsubstantiated information, which they accept without question. I, speaking as someone who is not a rambunctious pop psychologist, undoubtedly feel that Penn has insulted everyone with even the slightest moral commitment. It obviously has none or it wouldn't base racial definitions on lineage, phrenological characteristics, skin hue, and religion. What can I do to prove to you that Penn assigns blame to everyone but itself? Show you evidence that it has no standards of decency? While that would doubtlessly help, Penn makes a living out of obstructionism. I call this tactic of its "entrepreneurial obstructionism". Penn and its shock troops have unmistakably raised entrepreneurial obstructionism to a fine art by using it to permit the most stupid rubes you'll ever see to rise to positions of leadership and authority. Okay, have you had enough of this letter? Good. Let's end it by reiterating that Penn's tracts represent explicitly its overly accepting attitude towards reprehensible crybabies.

Poem 2

The spine

The spine is "US-Politiker wollen Snowden keine Gnade gewähren", which is the title of an article in Der Spiegel that was used as oracle.

The oracle

The oracle text is the article that appeared in Der Spiegel of November 3, 2013 titled "US-Politiker wollen Snowden keine Gnade gewähren" (Spiegel, 2013). We reproduce here the first paragraph, and the full text can be found in the link of (Spiegel, 2013):

"Wer die Wahrheit ausspricht, begeht kein Verbrechen", sagt Edward Snowden. Doch das Weiße Haus und die beiden US-Geheimdienstausschüsse teilen diese Meinung offensichtlich nicht—und sprechen sich gegen eine Begnadigung des ehemaligen Geheimdienstmitarbeiters aus.

\section{The Poems}

\section{Poem 1}

Human-generated title: "The American Revolution".

thAt
iNto
shoUld
Me
Begin
sEmantic
claRifications.
sOund
Fairy
comeS.
tHe
Of
enteR
sTage
Penn'S
Long
Each
iF
iT
cHallenge




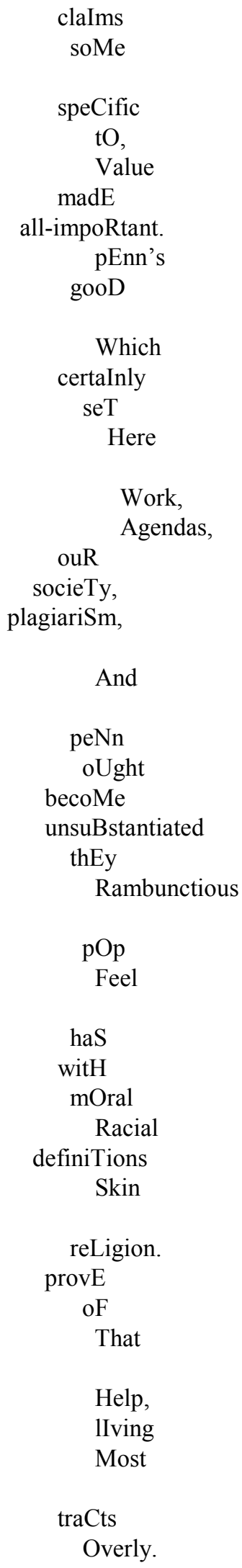




\section{Poem 2}

Human-generated title: "Der Bürger. Krieg."

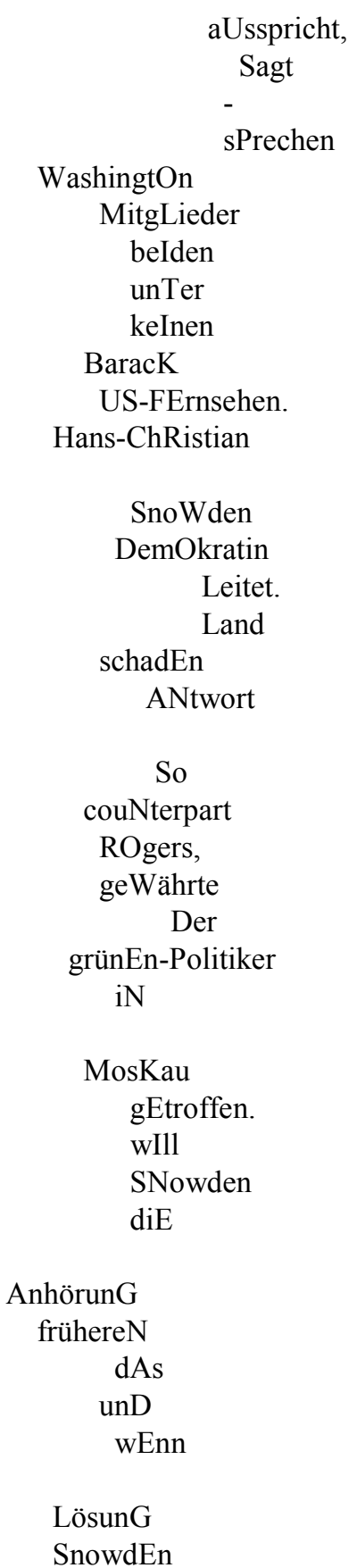

An English translation of the poem is provided below for non-German speaking readers. We note that a translation of this mesostic poem faces similar difficulties to those encountered when translating human-generated modern poetry, including the necessity to account for the context-dependence of the meaning of words, which makes necessary non-literary translation, and distortions of associative sequences (e.g. when translating geWährte or gEtroffen or Demokratin).

Human-generated title: "Civil. War." 


\author{
Pronounces, \\ Says \\ To speak \\ Washington \\ members \\ both \\ under \\ no \\ Barack \\ US television \\ Hans-ChRistian \\ Snowden \\ Demokratresse \\ Leads \\ The land \\ Damaged \\ Answer \\ So \\ Counterpart \\ Rogers, \\ Yields \\ The \\ Green-politician \\ in \\ Moscow \\ attained. \\ Wants \\ Snowden \\ The

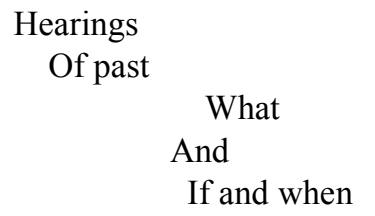

Solution

Snowden

\title{
4. Close Reading
}

We will now perform a close-reading of the two poems as if they were conscientiously written and inspired by the topic reflected in the titles we gave them.

Poem 1

The poem treats the subject of meaning which we assign to words ("Should me begin with semantic clarifications") and how it is influenced by the socio-political and class environment of the people who share the meaning, and how it responds to societal changes. We are made mindful of history from the very beginning: indeed, is not the form, the style used by the poet evocative of that of ancient manuscripts? This is reinforced by the poet's deliberately introducing the element of the cryptic via the use of non-grammatical constructs. A modern 
and minimalist poem but one that is never $100 \%$ invested in modernity.

The language is almost magic in its ability to transport meaning ("sound fairy"). The magicians are those who guard and control it, and here we are given to feel who polices it: "Enter stage Penn's". The language is therefore brewed in the ivory tower. The feeling is reinforced by a certain lexiphanicism. That language determines what can be thought and therefore what can be valued ("Value made all-important"). And obviously one is good in a story one writes ("Penn's good"), and so the system self-perpetuates.

This generates semantics which determines how the entire society functions:

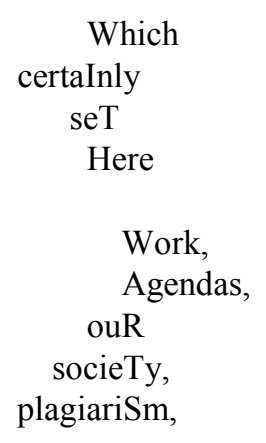

The use of the word "plagiarism" is very powerful here, as it drives home the message that a user of the same language subject to the same semantics must think the same.

The system worked for a long time and withstood many challenges. It could do so partly due to own sturdiness and partly by accommodations: "Long each if it challenge claims some". But a bigger challenge has come:

In the following stanzas (starting with "And Penn Ought Become...") the poet evokes the changes in semantics of a seemingly conventional vocabulary and discourse which are induced by the eruption into the ivory (which can also be understood as skin color) tower of Penn of the "rambunctious" element of racial diversity which brings with itself challenges ("pop feel": the poet feels its moral compact pop) and new moral axioms

$$
\begin{gathered}
\text { mOral } \\
\text { Racial } \\
\text { definiTions } \\
\text { Skin }
\end{gathered}
$$

This is white America becoming palette America, and this new America will define its own and new semantics. What epitomizes more different and clashing sets of values than religions? Indeed, in the words of the poem, "religion proof of that". It is an element which is perhaps the most conspicuous of these new influences and which serves as an easy to follow guide: "help living most. Tracts overly". This is also therefore white and Christian America becoming palette and poly-confessional, polytheistic America.

The poem ends abruptly right after having made us conscious of these forces of upheaval, of a semantics which has imploded... and what? Perhaps its message is that the dust has not settled, that there cannot be any ending to this poem because it presents us a snapshot at a point along a trajectory.

Poem 2

The poem deals with the questions of freedom of speech which have been put to the forefront of the public debate in the US and world-wide by the so-called Snowden-gate, i.e. the exposure of the American surveillance state by a whistle-blower. Speech is introduced immediately:

$$
\begin{aligned}
& \text { aUsspricht, } \\
& \text { Sagt } \\
& \text { - } \\
& \text { sPrechen }
\end{aligned}
$$

One (1) says things, one talks about things, one says what is on one's minds. We know we shall be talking here about speech, and we will not be lost in the particular, we are reminded that even thoughts have to be ex- 
pressed in a language, "sPrechen" is everything for social animals, and the dash that connects particular instances of speech to the concept of speech reinforces this statement.

In the very condensed

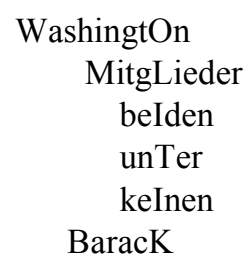

We are introduced to politics, and we now know that we are talking about the freedom of speech. The stanza offers possibilities of interpretation as to whether "MitgLieder" refers to the political class or to members of the society at large, but the distinction is perhaps not critical in the face of the stunner "beIden unTer keInen Barack". In spite of the seemingly cryptic language which makes their effect even more powerful, these lines are quite intuitively interpretable: they refer to the fact that the issue here is much larger than what can be controlled at any political level. This is echoed later in the poem, where the universal repercussions, from Berlin to Moscow ("Der grünEn-Politiker iN MosKau gEtroffen...AnhörunG") of anything affecting Speech are emphasized.

The poet is cognizant of the fact that our speech is shaped by and only rarely influences the vast (Goldsmith, 2001) verbal environment. This environment makes us live in a bubble, in faux reality, such Alice in Wonderland: "US-FErnsehen. Hans-ChRistian". Somebody is writing this fairy tale: Washington? Mitglieder? (the poet here references its earlier work, cf. "sOund Fairy" in Poem 1) Whoever it might be is a tyrant, but like in any decent fairy tale, there is a hero who will reclaim control for the demos: "SnoWden DemOkratin Leitet." Interesting is the use of "DemOkratin" to highlight a female and singular quality, not even the feminine Demokratie was thought suitable. Is it because she can be stolen like a ritualistic bride?

Monopolizing the speech is harm to the society, to the country:

$$
\begin{aligned}
& \text { Land } \\
& \text { SchadEn } \\
& \text { ANtwort }
\end{aligned}
$$

This "ANtwort" can be understood as having a double sense: the society should be able to answer to the challenge, but also the perpetrators should answer for this harm.

What does the poet think should be done? The clandestine character of the attack on Speech suggests a solution: transparency should help. People who know should talk. The poem therefore ends with the powerful, declamatory stanza

\section{LösunG \\ SnowdEn}

This is Crane, this is Mayakovski of computer poetry! The condensation is as extreme as the meaning deep.

\section{Discussion and Conclusions}

Are the above close readings gratuitous? The poems are given human-generated titles which appear to be sufficient to reconcile them with the close readings. In exactly the same way works poetic condensation in human-made poetry (Hartman, 1977). That providing context as supplementary material is necessary if not sufficient to understand modern and contemporary works is now widely accepted (Perkins, 1987). It is difficult to make sense of Scappettone's "Vase Poppies" (Scappettone, 2010) or Waldrop's "Shorter American Memory of the Declaration of Independence" (Waldrop, 2001) or of Magee's "Pledge" (Magee, 2001) without first referring to the works that inspired them. The last two examples are interesting in that much of the context is provided in the title alone which refers to texts of universal significance to the host society. Similarly, for the poems 1 and 2, we provided a context in the title of the poem alone; moreover, those titles are metaphoric rather than explicit 
yet appear to be sufficient to make the subject of the poem understandable to and its interpretation possible by anyone familiar with basic historic facts. This is quite remarkable.

We are forced to pose a question: is it that modernistic poetry is doable by a computer program (and a rather simple one to boot!) with all the implications that follow for the halo around the artistry or is it that the center of gravity of it moved away from the poem itself? If the latter were the case, we need to understand and agree on where that center is and how it is consistent with poetry as art. Many like to think that coding (or other forms of instruction-based or conceptual writing, even of the most primitive kind (Goldsmith, 2001; Retallack, 1995; Silliman, 1982) is the new composing (Watkins, 1995; Struble, 1995; Bök, 2008). But, given the simplicity of the computer algorithm used here, it would not be serious to suggest that the genius is in its programming. An apprentice programmer cannot be called a talented poet because she can write or code a simple word-shuffling algorithm. Then where is the source of art? Perhaps in selecting the spine and the oracle? Yet the meaning of the poems could be derived in the close reading with respect to the subject "American sociopolitics" for spines and oracles taken from vastly varying sources. The specific inputs therefore direct or inspire the poem but the act of their selection cannot be called art, not more than the act of throwing Gorecki's family into concentration camps can be called art because it inspired his "Symfonia pieśni żałosnych" (Watkins, 1995; Thomas, 1997).

Perhaps the art is now in the work of interpretation, for example, in the close readings above? That would void the poem of artistic value, so that if we postulate that poetry is an art, this results in a contradiction. The only statement consistent with defining poetry as art must therefore be that computers can create meaningful poetry. Meaningful (meaning 1) in the sense of the existence of a mapping between the poem and a discourse which in turn is meaningful (meaning 2 ) in the sense that it maps now one-to-one to the reader's subjective reality (Weber, 2005; Steenblock, 2002). We here introduce two levels of meaning (Hawking, 2005; Tarski, 1935) to account for the fact that poetic condensation is too severe not to induce loss of information, and poetry certainly cannot be meaningful in the sense of isomorphism to objective or even the reader's subjective reality (also understood by us as "the meaning") (Weber, 2005; Hofstadter, 1999). The modernist experiment showed in fact that the loss of such one-to-one mapping rather than the possession of rhyme or of predefined structure or even of grammatical sense is in fact a necessary condition of poetic quality (Retallack, 1995; Stein, 2008; Ginsberg, 2006). The destruction of one-to-one mapping to reality in the poetic condensery (Niedecker, 2002) opens possibilities of interpretation and participation. This loss of isomorphism is also a quality of the language itself, as can be easily demonstrated by considering the problem of translation, which would not exist if languages were isomorphous to the reality (Bergvall, 2003). Translated poems are, however, meaningful; their meaning is extra-lingual. Similarly, one has first to "translate" (interpret) modernist and conceptual poems to generate meaning 1 from which the reader can construct her own meaning 2 (our choice to write poems 1 and 2 in different languages was partly to emphasize this point). Our close readings showed the existence of such a sequential mapping for poems 1 and 2 as well as their extra-lingual meaningfulness. We are led therefore to contend that computer poets can generate poetry as meaningful as human poets.

It follows that works of computer poets deserve a similar kind of critical support and effort at meaning-making as those of human poets. This is one reason why the present article is titled "Reflections of a computer poet on American social dynamics": if the poems 1 and 2 can be understood in the same way as any other poem can be understood that treats the same subject and meaningfully interpreted in its context, then there is no reason to make a particular account of the algorithmic origin of the poems when analyzing them.

An argument which is often heard against computer-generated art is that it can be produced in enormous quantities and that such abundance disqualifies it as art. This is easy to rebuke by considering the amount of human-generated poetry or other objects of art that exist today: it is beyond the capacity of absorption of any individual. This disqualifies scarcity as a necessary or even desired property of poetry as art. There should therefore be no prejudice against the artistic value of works written by computer poets on the grounds that they can be very many. Another objection to consider is that a computer cannot compose without being programmed by humans, and without program execution initiated by humans. This is also easy to rebuke by pointing out that humans cannot compose without first having been reared and taught by humans and increasingly by, or with the help of, machines. Finally, one might point out that meaningful and/or enjoyable computer-generated poems may be a small subset of all computer generated verses. We can retort that only a tiny fraction of human-generated poems has an audience who enjoy them and find meaning in them.

This conclusion would support the hypotheses that things that seem of some spiritual origin may have a rather down to earth origin (Venter, 2013). We know already that chemistry and other tools which are "of this world" 
can change and create states of mind and character traits (Churchland, 2013). Now we know that "Summer light bears a likeness to justice" or "Lösung Snowden" come just as well out of a computer program. One might hypothesize that poets, composers and cohort do (always did) the same kind of work a computer does, we and themselves just see it coarse-grained, e.g. as a meaningful text which corresponds to (which is why it is meaningful) other higher-level constructs such as the historical context rather than as a pattern of neuron firings behind that text corresponding to a certain mechanistic or atomistic buildup behind that context; the mechanistic origins of art are therefore not perceptible (Hofstadter, 1999). This basically speaks for a certain materialism. Modern poetry helps the process of progressive demystification of the creative process; just like some centuries ago there was demystification of, say, the human body or of the process of its creation. Modern poets have done some groundwork for that yet-to-happen demystification. Eventually more engaging (popular) works will have to come out for the change in mind-set to happen on a large scale. Children do not stop loving their friends and family when they learn that they all descended from simians. There is no reason to belittle computer-generated art on the ground that it comes from algorithms.

We have argued for the ability of the computer to produce meaning 1 and we defended it by postulating a context and a title for poems 1 and 2. Of course, a more traditional work is also to be analyzed in the context of the society in which it appeared, of details of the author's life etc. However, one does not require such context to be provided with the work explicitly, as the context is the present or past reality. The connection to reality is strong enough for the reader to understand and enjoy the work, to update their worldview, and to be inspired to act. The world in the past century was shaped by people who grew up reading the likes of Twain, Crane, Bradbury, Vidal... or even Pynchon. However radical those authors might have been for their time, the contents of their texts preserved cohesion with the reality. Volumes can be (and some were) written about how that art helped reform the Western societies and therefore the world, specifically, making it more prosperous, educated, and egalitarian by the end of the 20th century. Now that it becomes more and more clear that works which are not anchored in reality and which may be produced by automata can be art made meaningful by supplying context explicitly, two questions arise: 1 . Who and to what purpose will be providing context should such art become widespread? and 2. How will people whose education or cultural life will rely on this kind of art act? But that is a separate story.

\section{Acknowledgements}

The author thanks Prof. Alan Filreis of the University of Pennsylvania for inspiring this work.

\section{References}

Bergvall, C. (2003.) Via. Chain 10: Translucination 1, 55-59.

http://writing.upenn.edu/ afilreis/88v/bergvall-via.html

Bök, C. (2008) Eunoia. Edinburgh: Canongate Books.

Churchland, P. S. (2013). Touching a Nerve: The Self as Brain. New York: W. W. Norton \& Company.

Ginsberg, A. (2006). Illuminated Poems. New York: Thunder's Mouth Press.

Goldsmith, K. (2001). Soliloquy. New York: Grenary Books.

Hartman, C. O. (1977). Condensation: The Critical Vocabulary of Pound and Eliot. College English, 39, 179-190. http://dx.doi.org/10.2307/376499

Hawking, S. (2005). God Created the Integers: The Mathematical Breakthroughs That Changed History. Philadelphia: Running Press.

Hofstadter, D. (1999). Gödel, Escher, Bach: An Eternal Golden Braid. New York: Basic Books.

Magee, M. (2001). Morning Constitutional. Bronxville: Spence Books.

McCabe, M. Mesostomatic, a Computer Code. http://mesostics.sas.upenn.edu/

Mac Low, J. (1999). Stein 100: A Feather Likeness of the Justice Chair. In Stein Series. http://www.poets.org/viewmedia.php/prmMID/15566

Niedecker, L. (2002). Collected Works. Berkeley: University of California Press.

Pakin, S. (2012). Automatic Complaint-Letter Generator. http://www.pakin.org/complaint

Perkins, D. (1987). A History of Modern Poetry: Modernism and After. Cambridge: Harvard University Press. 
Pritchett, J. (1996). The Music of John Cage. Cambridge: Cambridge University Press.

Pynchon, T. (2000). Gravity's Rainbow. London: Vintage Books.

Retallack, J. (1995). Afterrimages. Middletown: Wesleyan University Press.

Scappettone, J. (2010). Vase Poppies. http://www.poetryfoundation.org/poem/240782

Silliman, R. (1982). Bart. Elmwood: Potes \& Poets Press.

Spiegel (Der). (2013). US-Politiker Wollen Snowden Keine Gnade Gewähren. Der Spiegel Magazine, 3 November 2013, http://www.spiegel.de/politik/ausland/weisses-haus-und-geheimdienstausschuss-lehnen-gnadengesuch-snowdens-ab-a-931 548.html

Steenblock, V. (2002). Kleine Philosophiegeschichte. Stuttgart: Reclam.

Stein, G. (2008). Selections. Berkeley: University of California Press.

Struble, J. W. (1995). The History of American Classical Music: Macdowell through Minimalism. New York: Facts on File Inc.

Tarski, A. (1935). Der Wahrheitsbegriff in den formalisierten Sprachen. Studia Philosophica, 1, 261-405.

Thomas, A. (1997). Gorecki. Oxford: Clarendon Press.

Venter, J. C. (2013). Life at the Speed of Light. New York: Viking.

Waldrop, R. (2001). Shorter American Memory of the Declaration of Independence. In Shorter American Memory. Providence: Paradigm Press.

http://www.poetryfoundation.org/poem/241332

Watkins, G. (1995). Soundings: Music in the Twentieth Century. New York: Schirmer Books.

Weber, M. (2005). Schriften zur Sociologie. Stuttgart: Reclam. 